\title{
Na-Dene Language
}

National Cancer Institute

\section{Source}

National Cancer Institute. Na-Dene Language. NCI Thesaurus. Code C161913.

family of Native American languages that includes at least the Athabaskan languages,

Eyak, and T lingit languages. 